\title{
BELAJAR BERSAMA MASYARAKAT (BBM) MELALUI KEGIATAN KKN DALAM BIDANG PENDIDIKAN, LINGKUNGAN, EKONOMI, DAN AGAMA
}

\section{LEARNING WITH THE COMMUNITY THROUGH KKN ACTIVITIES IN EDUCATION, ENVIRONMAN, ECONOMY, AND RELIGION}

\author{
R Hartono $^{1}$, A Kurniawati ${ }^{1}$, dan DD Prasetyo ${ }^{1 a}$ \\ 1Program Studi Pendidikan Guru Sekolah Dasar, Fakultas Keguruan dan Ilmu Pendidikan, \\ Universitas Djuanda Bogor, Jl. Tol Ciawi No.1 Kotak Pos 35 Bogor 16720 \\ a Korespondensi: Dika Dwi Prasetyo, Email: dikaprasetyo71@gmail.com \\ (Diterima: 10-02-2017; Ditelaah: 12-02-2017; Disetujui: 06-04-2017)
}

\begin{abstract}
Learning with the community is an activity carried out by students who have a general purpose to support and initiate all development processes in society in order to improve the welfare of the community. This activity was followed by students of Djuanda University Bogor divided by 20 groups in seven sub-districts of Bogor Regency. There are several aspects of education, health, environment, and local economy. Through the KKN program, students are expected to improve the quality of their family life and themselves. Being a family capable of dealing with the problems that come. Students succeeded in establishing programs covering the health field of clean Friday programs, healthy roads, the economic field of culinary innovation with new innovations, crafts, seminars and waste processing and achieving 80 percent target with the main constraints of limited capital and synergy between private, local government.
\end{abstract}

Keywords: community empowerment, community learning, health, economy.

\begin{abstract}
ABSTRAK
Belajar bersama masyarakat adalah kegiatan yang dilaksanakan oleh mahasiswa yang mempunyai tujuan umum mendukung dan memprakarsai segala proses pembangunan di masyarakat demi meningkatkan kesejahteraan masyarakat. Kegiatan ini diikuti oleh mahasiswa Universitas Djuanda Bogor dibagi 20 kelompok di tujuh Kecamatan Kabupaten Bogor. Ada beberapa aspek yaitu pendidikan, kesehatan, lingkungan, dan ekonomi lokal. Melalui program KKN diharapkan Mahasiswa dapat meningkatkan kualitas kehidupan keluarganya dan diri sendiri. Menjadi keluarga yang mampu menghadapi persoalan-persoalan yang datang. Mahasiswa berhasil membentuk program yang meliputi bidang kesehatan melakukan program Jumat bersih, jalan sehat, bidang ekonomi menginovasi kuliner dengan berbagai inovasi-inovasi baru, kerajinan, seminar dan pengolahan sampah dan mencapai target 80 persen dengan kendala utama terbatasnya modal dan sinergitas antara masayarat, swasta dan pemerintah daerah.
\end{abstract}

Kata kunci: pemberdayaan masyarakat, belajar bersama masyarakat, kesehatan, ekonomi.

Hartono R, Kurniawati A, dan DD Prasetyo. 2017. Belajar bersama masyarakat (BBM) melalui kegiatan kkn dalam bidang pendidikan, lingkungan, ekonomi, dan agama. Qardhul Hasan: Media Pengabdian kepada Masyarakat 3(1): 74-85. 


\section{PENDAHULUAN}

Pembangunan Nasional merupakan pembangunan manusia seutuhnya dan seluruhnya bagi masyarakat Indonesia. Pembangunan bukan hanya berbentuk fisik atau material tetapi aspek psikis atau rohani. Selain itu pembangunan juga harus dilakukan secara merata keseluruh masyarakat Indonesia agar dinikmati secara merata pula oleh masyarakat Indonesia karena pembangunan merupakan sebuah kewajiban masyarakat Indonesia.

Perguruan tinggi merupakan penghantar dan unsur yang ada dari kewajiban tersebut. Sehingga, perguruan tinggi berkewajiban memberikan tenaga profesional yang akan menjadi penerus pembangunan bangsa ini demi kesejahteraan masyarakat. Untuk mewujudkan tujuan dari lembaga pendidikan, maka kegiatan Kuliah Kerja Nyata (KKN) sebagai mata kuliah yang dianggap bisa mewadahi kegiatan tersebut dengan berdasarkan pada Tap. MPR Nomor: IV/MPR/1973 yang berisi tentang peningkatan peranan Perguruan Tinggi dalam usaha pembangunan.

Kuliah kerja nyata merupakan kegiatan yang dapat memberikan pengalaman pada mahasiswa untuk bermasyarakat. Namun sebelum mahasiswa turun kemasyarakat, perlu adanya pembekalan berbagai pengetahuan yang berkaitan erat dengan kegiatan masyarakat. Sehingga ketika mahasiswa terjun ke dalam masyarakat bisa benar-benar menerapkan Tri Dharma Perguruan Tinggi. Belajar Bersama Masyarakat (BBM) adalah sebuah kegiatan salah satu program Kuliah Kerja Nyata (KKN) kelompok 20 FKIP Universitas Djuanda. Pelaksanaan KKN sebagai bentuk dharma bakti aktifitas keilmuan dan non keilmuan mahasiswa kepada masyarakat dengan melakukan kegiatan yang berkolerasi langsung sesuai kebutuhan masyarakat. BBM yang dilakukan memiliki maksud untuk meningkatan relefansi pendidikan perkembangan dan kebutuhan masyarakat akan ilmu pengetahuan dan teknologi untuk tercapainya pembangunan yang semakin meningkat.

Selain itu BBM dapat memberikan kesempatan pada mahasiswa untuk menjadi penyemangat dalam pemberdayaan masyarakat. Dengan demikian BBM diharapakan dapat memberikan pengalaman dan pembelajaran kepada mahasiswa sebagai penerus pembangunan yang lebih menghayati permasalahan yang ada di masyarakat, BBM juga untuk mengurangi berbagai masalah yang ada di masyarakat secara prakmatis dan Interdispliner sebagai nilai tambahan tercapainya harapan membentuk masyarakat yang benar-benar menjadi berdaya untuk meningkatkan daerah secara mandiri, sehingga dapat membantu tercapainya cita-cita pembangunan Nasional.

Permasalahan yang dapat diangkat dari Wilayah KKN, diantaranya adalah kurangnya pengembangan pengetahuan sumber daya masusia (SDM), khususnya di bidang pendidikan, lingkungan, ekonomi dan agama. Untuk itulah sebagai wujud kepedulian dan sekaligus penggerak yang didukung oleh sumber daya manusia (dalam hal ini mahasiswa) merasa perlu untuk berpartisipasi khususnya di wilayah pelaksanaan KKN. Karena diharapkan mampu untuk mengembangkan atau memotivasi perkembangan ekonomi di wilayah tersebut. Penyelengaraan kegiatan Kuliah Kerja Nyata (BBM) di harapkan meningkatkan sifat empati dan kepedulian mahasiswa terhadap problemmatikannya dalam kehidupan secara nyata dimana mahasiswa dapat mengimplementasikan yang ada untuk membantu masyarakat secara langsung.

\section{MATERI DAN METODE}

\section{Materi}

Pembangunan bukan hanya berbentuk fisik atau material tetapi aspek psikis atau rohani. Selain itu pembangunan juga harus dilakukan secara merata keseluruh masyarakat Indonesia agar di nikmati 
merata pula oleh masyarakat Indonesia karena pembangunan merupakan sebuah kewajiban masyarakat Indonesia.

Perguruan tinggi merupakan penghantar dan unsur yang tidak lepas dari kewajiban tersebut. Sehingga, perguruan tinggi berkewajiban memberikan tenaga profesional yang akan menjadi penerus pembangunan bangsa ini demi kesejahteraan masyarakat. Untuk mewujudkan tujuan tersebut, maka ditetapkanlah Kuliah Kerja Nyata (KKN) sebagai salah satu mata kuliah yang dianggap bisa mewadahi kegiatan tersebut dengan berdasar pada Tap. MPR Nomor: IV/MPR/1973 yang berisi tentang peningkatan peranan Perguruan Tinggi dalam usaha pembangunan.

Kukerta adalah kegiatan yang dapat memberikan pengalaman dan pembelajaran bagi mahasiswa dalam bermasyarakat. Namun sebelum mahasiswa turun kemasyarakat, perlu adanya pembekalan berbagai pengetahuan yang berkaitan erat dengan kegiatan masyarakat. Sehingga ketika mahasiswa terjun kedalam masyarakat bisa benar-benar menerapkan ilmu yang telah di dapat di perkulihan.

Kuliah Kerja Nyata ini berada di Kampung Rahong Hilir Rt 03/08 Dusun 4 Desa Tegallega Kecamatan Cigudeg Kabupaten Bogor. Kelompok 20 merencanakan 5 (lima) program pokok pengabdian terhadap masyarakat tempat kelompok 20 melaksanakan KKN.

Selain itu BBM sebagai pemberdayaan masyarakat. Dengan demikian BBM diharapkan dapat memberikan pengalaman dan pembelajaran bagi mahasiswa untuk menghadapi masalah di masyarakat secara prakmatis dan Interdispliner. Kemudian sebagai nilai tambahan mahasiswa tercapainya harapan dapat membentuk masyarakat yang benar-benar menjadi berdaya untuk meningkatkan tercapainya pembangunan nasional.

Delapan program kegiatan ini, kelompok 20 merupakan hasil dari obsevasi sebelum pelaksanaan KKN. Selain program tersebut masih ditunjang beberapa program kreatifitas dan penunjang.

\section{Metode}

Pengamatan merupakan pembahasan yang diambil dari hasil pengamatan yang ada di Desa Tegallega pada metode pengamatan tersebut penulis melakukan observasi langsung terhadap kegiatan-kegiatan dan mengetahui secara langsung permasalahan yang ada di lokasi pelaksanaan proses kegiatan-kegiatan mahasiswa Fakultas Keguruan dan Ilmu pendidikan (FKIP) Universitas Djuanda di Desa Tegallega Kecamatan Cigudeh Kabupaten Bogor.

Dari bidang pendidikan, permasalahan tersebut di selesaikan dengan memfokuskan pada peningkatan minat terlebih dahulu sebelum proses belajar dan mengajar. Permasalahan lainnya adalah tentang biaya (SPP,buku,dan alat tulis) tidak adanya program bimbingan belajar, kurangnya mutu pendidikan dasar mengurangi buta huruf bagi lanjut usia telah berhasil dilaksanakan. Kemudian pelaksanaan bimbingan belajar/les memberikan semangat belajar dan meningkatan pengetahuan materi pelajaran lebih meningkat bagi siswa.

Dari bidang lingkungan, mengadakan jumat bersih (jumsih) di lingkungan sekitar yang pelaksanaan programnya telah tercapai untuk meningkatkan kebersihan dan kesehatan di lingkungan sekitar. Pembuatan bak sampah di mana dalam pelaksanaan ini dapat menciptakan kesadaran untuk membuang sampah pada tempatnya. Kurang pedulinya masyarakat terutama terhadap sampah rumah tangga.

Banyak sampah warga yang tidak berguna hanya di buang sekitar terutama di sungai yang pada akhirnya membuat lingkungan menjadi kurang nyaman dan tidak bersih. Melihat permasalahan yang terjadi di lingkungan sekitar, kami berinisiatif untuk mengajarkan tentang pengolahan sampah agar lebih bermanfaat dan dapat menjadi kompos yang berguna bagi masyarakat sekitar khususnya untuk pertanaman. 
Sementara dalam bidang infrastruktur, masih kurangnya tatanan wilayah di Desa Tegallega yang kaya akan sumber daya alam yang subur. Sekaligus sebagai mahasiswa Universitas Djuanda Bogor yang juga berkewajiban untuk menyebarluaskan semangat konservasi, maka kami ingin melakukan pembenahan dengan membenahi tempat sampah yang ada di lingkungan untuk menjadi lingkungan yang sehat dan bersih.

Serta tidak lupa pembuatan tempat sampah yang selalu menjadi salah satu program kegiatan Universitas Djuanda Bogor dalam upaya menyebarkan semangat hidup sehat, bersih dan nyaman. Mengadakan jumat bersih (jumsih) di lingkungan sekitar yang pelaksanaan programnya telah tercapai untuk meningkatkan kebersihan dan kesehatan di lingkungan sekitar. Pembuatan bak sampah di mana dalam pelaksanaan ini dapat menciptakan kesadaran untuk membuang sampah pada tempatnya dan mendaur ulang sampah plastik, kertas, dll.

Untuk dijadikan berbagai kerajinan tangan misalnya botol bekas, kantong plastik, kertas koran, botol air mineral, kain/bahan sisa. Dengan didaur ulangnya sampah-sampah tersebut secara tidak langsung masyarakat mengurangi pencemaran lingkungan. Kurang pedulinya masyarakat terutama terhadap sampah. Banyak sampah tidak berguna hanya di buang di lingkungan sekitar terutama di sungai yang pada akhirnya membuat lingkungan menjadi kurang nyaman sebagai tempat tinggal. Melalui kegiatan ini kami mengajarkan tentang pengolahan sampah dan menjadi kompos yang bermanfaat bagi warga sekitar.

Sementara di bidang infrastruktur,. Sekaligus sebagai mahasiswa Universitas Djuanda Bogor yang juga berkewajiban untuk menyebarluaskan semangat konservasi, maka kami ingin melakukan pembenahan dengan membenahi sampah yang ada di desa untuk menjadi lingkungan yang bersih dan sehat.
Serta tidak lupa pembuatan tempat sampah yang selalu menjadi program Universitas Djuanda Bogor dalam upaya menyebarkan semangat hidup sehat dan bersih. Mengadakan jumat bersih (jumsih) di lingkungan sekitar yang pelaksanaan programnya telah tercapai untuk meningkatkan kebersihan dan kesehatan di lingkungan sekitar. Pembuatan bak sampah di mana dalam pelaksanaan ini dapat menciptakan kesadaran untuk membuang sampah pada tempatnya seperti botol beka, plastik, kertas, dll.

Untuk dijadikan berbagai kerajinan tangan misalnya botol bekas, Kantong plastik, kertas koran, botol air mineral, kain/bahan sisa. Dengan didaur ulangnya sampah secara tidak langsung masyarakat mengurangi pencemaran lingkungan. Dari bidang ekonomi, menginovasi berbagai olahan makanan dimana bahan utama olahan makanan di ambil dari potensi alam yang ada di daerah sekitar dan pelaksanaannya sudah tercapai yaitu pengolahan gadung menjadi keripik gadung dengan berbagai varian rasa, pengolahan durian menjadi wajik durian dimana cara pengemasan wajik tersebut unik dan pengolahan gula aren menjadi es krim gula aren yang sangat nikmat dan diminati banyak orang. Banyak permasalahan yang dijumpai yang berkenaan dengan keadaan pemasaran. Pelatihan bukan saja dilakukan namun harus memiliki tindak lanjut serta kesadaran untuk merubah pola kelakuan yang telah lakukan sebelumnya. Kesadaran untuk berubah juga perlu di tingkatkan agar memperoleh hasil yang baik dan pasti.

Dari bidang agama, mengadakan pembelajaran BTAQ (Baca Tulis Alqur an) dan tajwid di mana di dalam pelaksanaan kegiatan ini, warga semangat dan antusias. Dan program ini sudah terlaksana dan tercapai. Sarana prasarana peribadatan yang ada di Desa Tegallega Kecamatan Cigudeg Kabupaten Bogor terdiri dari 5 masjid besar, dan 10 mushola yang tersebar di setiap kampung.

Di Kampung Rahong Hilir Desa Tegallega Kecamatan Cigudeg Kabupaten Bogor kami 
mengadakan pembelajaran BTAQ (Baca Tulis Alquran) dan tajwid untuk anak dan juga lansia. Dimana dalam pelaksanaan kegiatan ini, warga sangat semangat dan antusias. Dan kegiatan ini dapat terlaksana dan tercapai. Dengan diadakannya pembelajaran BTAQ (Baca Tulis Alqur an) dan Tajwid ini diharapkan warga bisa meningkatkan mutu pembacaan, penulisan dan tempat keluarnya huruf (makharijul huruf) dan juga untuk meningkatkan mutu baca tulis Al-Qur'an warga Kampung .Rahong Hilir Desa Tegallega Kecamatan Cigudeg Kabupaten Bogor.

\section{HASIL DAN PEMBAHASAN}

\section{Hasil}

Selama 40 hari pelaksanan KKN Belajar Bersama Masyarakat (BBM) Universitas Djuanda Bogor, para pelaksana kegiatan BBM ini berhasil membantu masyarakat Kecamatan Cigudeg , Desa Tegallega Kampung Rahong Hilir. KKN dilaksanakan dengan menghadirkan mahasiswa ke masyarakat. Sebagai pembelajaran di lingkungan masyarakat, memerlukan tahapan mempersiapkan diri untuk menghadapi permasalahan di masyarakat. Oleh karena itu, tahapan yang perlu dilaksanakan setelah pembekalan adalah melakukan observasi ke Kampung Rahong Hilir Kecamatan Cigudeg Kabupaten Bogor yang akan ditempat mahasiswa KKN tersebut. Kegiatan observasi ini dilakukan untuk mengetahui permasalahan yang ada di pemerintahan, pendidikan, kultur sosial, keagamaan, ekonomi, dan hukum.

Hasil kegiatan observasi bertujuan untuk dapat menyajikan atau merumuskan program kerja tersebut dapat menjawab permasalahan yang ada. Permasalahan yang dapat diangkat dari Wilayah kegiatan (KKN), diantaranya adalah kurangnya pengembangan pengetahuan sumber daya masusia (SDM), khususnya di bidang pendidikan, lingkungan, ekonomi dan agama.
Untuk itulah sebagai wujud kepedulian dan sekaligus penggerak yang didukung oleh sumber daya manusia (dalam hal ini mahasiswa) merasa perlu untuk berpartisipasi khususnya di wilayah pelaksanaan KKN. Karena mengharapkan untuk mengembangkan atau memotivasi perkembangan ekonomi di wilayah tersebut. Penyelengaraan kegiatan (BBM) di harapkan meningkatkan sifat empati dan kepedulian mahasiswa terhadap problemmatikannya dalam kehidupan secara nyata dimana mahasiswa dapat mengimplementasikan ilmu yang didapat untuk membantu masyarakat secara langsung.

Pada waktu observasi peserta KKN melakukan pengamatan secara langsung tentang kondisi Kampung Rahong Hilir Kecamatan Cigudeg Kabupaten Bogor dengan pegawai kecamatan setempat dan bersilaturahmi dengan perangkat Kampung Rahong Hilir untuk mencari data dalam segi pemerintahan Kampung Rahong Hilir, Kultur sosial, keagamaan, ekonomi, dan kesehatan yang diterapkan di Kampung Rahong Hilir Desa Tegallega Kecamatan Cigudeg Kabupaten Bogor.

Adapun kegiatan-kegiatan yang sudah dilakukan antara lain dibidang pendidikan, Bidang lingkungan, Bidang ekonomi dan Bidang Agama. Input dan output hasil KKN. Hasil yang dicapai selama pelaksanaan KKN di Desa Tegallega Kecamatan Cigudeg Kabupaten Bogor yaitu semua kegiatan ini direncanakan dapat terlaksana dengan baik dan lancar. Selain itu berbagai program tambahan juga dapat dijadikan tambahan pengalaman bagi kelompok KKN dalam bersosialisasi dengan masyarakat. Dari keseluruhan observasi yang dilakukan, mendapatkan informasi kegiatan-kegiatan tersebut dipaparkan sebagai berikut.

\section{Bidang Pendidikan}

Pendidikan adalah komponen yang dapat meningkatkan pengetahuan masyarakat menjadi lebih baik. Dengan berkembangnya kehidupan masyarakat yang dihadapi pun bertambah terutama dalam bidang pendidikan. Permasalahan pada dibidang 
pendidikan di kampung Rahong Hilir Desa Tegallega kecamatan Cigudeg Kabupaten Bogor yaitu kurangnya keterampilan komputer, bahasa inggris, kesenian, keterampilan dan matematika pada pemuda pemudi. Ini adalah permasalahan yang harus diselesaikan untuk peningkatan minat terlebih dahulu sebelum melakukan proses belajar mengajar. Permasalahan lain berupa biaya (SPP, buku, dan alat tulis) bimbingan belajar, minat belajar dasar. Kampung Rahong Hilir belum memiliki SMA, sebagai salah satu faktor kurangnya mutu pendidikan karena anak-anak yang telah tamat SMP/MTs harus melewati perjalanan yang jauh ke Sekolah Menengah Atas. Banyak siswa yang kedayah, sekolah asrama, atau di luar daerah. Pendidikan dibidang agama diadakan rutin setiap hari, dan sudah diterapkan pada anak-anak yang berusia sekitar 4 tahun lebih di TPA.

Permasalahan dibidang pendidikan yang terjadi di masyarakat adalah kurangnya kesadaran tentang pentingnya pendidikan di dalam kehidupan. Terbukti dengan jumlah sebagian besar penduduk tingkat pendidikannya adalah SD yang mencapai 1.564 orang, penduduk dengan tingkat pendidikan SMP berjumlah 571 orang, SMA 293 orang dan perguruan tinggi 17 orang.

Sebuah hal yang cukup mengagetkan melihat wilayah Tegallega yang berada di wilayah Kabupaten Bogor. Selain itu meskipun Tegallega memiliki letak yang berada di wilayah Kabupaten Bogor, namun kehidupan pendidikan bagi anak-anak dan juga bagi para pemuda yang kurang mendapat respon dan juga menjadi perhatian yang lebih agar bisa mencapai kondisi yang optimal.

Mengacu pada tujuan Universitas Djuanda Bogor yang merupakan pencetak-pencetak calon pengajar bangsa, sekaligus pencetak calon konserver-konserver yang peduli akan karakter bangsa, maka kami mengadakan bimbingan belajar bagi anak-anak SD ada di wilayah tersebut, bagi orang tua yang berusia lanjut (lansia) kami ingin melaksanakan bimbingan belajar mengenal huruf agar lebih mengembangkan kualitas SDM bangsa kita.

Selain dari permasalahan tersebut di Desa Tegallega terdapat 1 PAUD, 1 taman kanakkanak (TK), dan 4 SD/MI 3 SD Negeri yaitu SDN Nunggaherang 1 dan 2, SDN Batu Jajar 04, dan 1 MI yaitu MI Anuriyatul Khoiriyah. Namun PAUD di kelurahan tersebut kurang begitu optimal ditinjau dari segi pelaksanaannya sendiri. PAUD yang di bentuk di kelurahan tersebut terbentuk atas insiatif dari perseorangan.

Melihat berbagai fenomena yang ada banyak berbagai permasalahan seperti halnya masih minimnya kesadaran masyarakat akan pentingnya pendidikan yang menunjukan lemahnya karakter dan mentalitas bangsa kita. Sehingga kembali mengacu pada program Universitas Djuanda Bogor terutama dalam konservasi yang di sini juga merujuk melakukan penanaman pembiasaan menyadarkan pentingnya dunia pendidikan. Mengurangi buta huruf orang tua yang berusia lanjut telah berhasil dilaksanakan. kegiatan ini dilakukan dalam seminggu 3 kali pertemuan yaitu pada hari Selasa, Rabu dan Jumat. Kemudian pelaksanaan bimbingan belajar/les dan memberikan semangat belajar dan juga meningkatkan kemampuan dalam mengetahui materi pelajaran lebih meningkat bagi siswa dan dengan diadakannya seminar pendidikan dapat memotivasi masyarakat sekitar dan memberikan wawasan mengenai pendidikan terhadap orang tua yang masih rendah di pendidikan tersebut. Kegiatan seminar dilaksanakan di SD/MI Anuriyatul khoyriyyah dengan mengundang masyarakat Kp. Rahong Hilir yang ada di Desa Tegallega.

\section{Bidang Kesehatan}

Kesehatan dan kebersihan perlu di perhatikan. Karena tidak ada penyakit yang harus ditangani dengan serius, kalaupun ada masih dakam skala yang kecil. Permasalahan yang timbul di Kampung Rahong Hilir Desa Tegallega Kecamatan Cigudeg Kabupaten Bogor seperti kegiatan Jumsih (Jumat 
Bersih) akan aktif dan harus dilaksanakan secara terus menerus oleh warga sekitar, namun perhatian warga terhadap kegiatan tersebut kurang, yang diakibatkan kesibukan warga desa dalam bertani, dikarenakan masyarakat mayoritas sebagai petani sehingga kegiatan tersebut, warga lebih baik waktunya untuk beristirahat. Pengolahan sampah yang kurang baik dan tidak adanya sarana yang menunjang untuk kebersihan lingkungan. Kebersihan lingkungan masih sangat perlu diperhatikan. Sampah masih banyak berserakan di sekitar Kampung Rahong Hilir Desa Tegallega Kecamatan Cigudeg Kabupaten Bogor karena kurangnya perhatian warga terhadap kebersihan lingkungan Kampung Rahong Hilir Desa Tegallega Kecamatan Cigudeg Kabupaten Bogor. Hal dilihat dari minimnya minat warga agar membuang sampah pada tempatnya. Sebagaian besar selokan pun banyak sampah-sampah yang membuat selokan menjadi tersumbat. Kemudian kurangnya warga dalam kesadaran membuang sampah di pinggir sungai yang menyebabkan pencemaran di sungai, sungai menjadi bau dan kotor. Oleh karena itu, pembersihan perlu melakukan kegiatan diadakan gotong royong dan jumat bersih (Jumsih)

Berbagai masalah di bidang keseharan dan lingkungan hidup juga di miliki oleh Kampung Rahong Hilir Desa Tegallega Kecamatan Cigudeg Kabupaten Bogor di antaranya:

a. belum memiliki posyandu atau puskesmas;

b. kurangnya penyuluhan kesehatan;

c. masyarakat belum sadar akan pentingnya menjaga kesehatan lingkungan;

d. pengolahan sampah belum baik.

Permasalahan dalam bidang kesehatan yang terjadi Kampung Rahong Hilir Desa Tegallega kecamatan Cigudeg Kabutan Bogor adalah kurangnya kesadaran masyarakat terhadap lingkungan sehingga rentan terkena berbagai macam penyakit.
Penyakit yang sering diderita atau di keluhkan di masyarakat adalah penyakit kulit. Masyarakat masih kurang peduli tentang bagaimana menjaga lingkungan dan tubuhnya sendiri, kemudian juga bagaimana menjaga kesehatan dan kenyamanan lingkungan tentang warga Desa Tegallega membuat kami berinisiatif bahwa dibutuhkan sosialisasi tentang kesehatan bagi masyarakat.

Sarana prasarana yang ada di Desa Tegallega yang ada yaitu 2 klinik pribadi dan 1 PUSTU (Puskesmas Pembantu). Untuk membantu warga desa tegallega dalam menyadarkan dan mengobati penyakit yang diderita warga sekitar.

\section{Bidang Lingkungan}

Bidang Lingkungan Kurang pedulinya masyarakat terutama terhadap sampah. Banyak sampah warga tidak berguna hanya di buang sembarangan sekitar terutama di sungai yang pada akhirnya membuat lingkungan menjadi kurang nyaman dan tidak bersih. Mengacu pada slogan kita tentang mengelolah dan meminimalkan sampah, maka kami mengajarkan tentang mengelolah sampah dan sampah menjadi kompos yang berguna bagi masyarakat.

Sementara di bidang infrastruktur, melihat kurang tertatanya wilayah Tegallega meskipun sebenarnya wilayahnya cukup subur. Sekaligus sebagai mahasiswa Universitas Djuanda Bogor yang juga berkewajiban untuk menyebarluaskan semangat konservasi, maka kami ingin melakukan pembenahan dengan membenahi dan mengelolah sampah untuk menjadi tempat lingkungan yang sehat dan bersih.

Serta tidak lupa pembuatan tempat sampah yang selalu menjadi program kegiatan Universitas Djuanda Bogor dalam upaya menyebarkan semangat hidup sehat dan bersih. Mengadakan jumat bersih (jumsih) di lingkungan sekitar pelaksanaan programnya telah tercapai untuk meningkatkan kebersihan dan kesehatan di lingkungan sekitar. Pembuatan bak sampah di mana dalam pelaksanaan ini dapat menciptakan kesadaran dalam kebiasaan 
membuang sampah pada tempatnya dan mendaur ulang sampah plastik, kertas, dll dan membuat sampah menjadi kompos.

Untuk dijadikan berbagai kerajinan tangan misalnya botol bekas, kantong plastik, kertas koran, botol air mineral, kain/bahan sisa. Dengan didaur ulangnya sampah secara tidak langsung masyarakat mengurangi pencemaran lingkungan.

\section{Bidang Transportasi, Komunikasi dan Informasi}

Bidang Transportasi, Komunikasi dan Informasi Pada bidang ini, Kampung Rahong Hilir Desa Tegallega Kecamatan Cigudeg Kabupaten Bogor, juga masih bermasalah dengan minimnya fasilitas yang ada di lingkungan masyarakat sehingga membuat masyarakat menjadi tidak menggunakan fasilitas tersebut secara maksimal. Permasalahan dalam transportasi komunikasi dan informasi diantaranya :

a. Pembuangan air Limbah Rumah Tangga belum teratur.

b. Drainase yang masih kurang dan tidak terawat.

c. Sarana olahraga yang masih kurang bahkan di Kampung Rahong Hilir Desa Tegallega Kecamatan Cigudeg Kabupaten Bogor belum ada.

d. Jalan- jalan di dusun masih belum aspal (berdebu ketika musim kemarau dan becek ketika musim hujan ).

e. Kurangnya sarana dan prasarana penunjang kantor .

Untuk sarana prasarana transportasi, komunikasi dan informasi di Kampung Rahong Desa Tegallega masih sangat terbatas terutama untuk sarana prasarana komunikasi dan informasi.

Untuk sampai di Desa Tegallega sangatlah sulit, apalagi jika kita tidak memiliki kendaraan pribadi. Karena di desa tersebut masih sangat sulit untuk mendapatkan transportasi umum. Sebagian besar kendaraan disana yaitu tronton dan truk dan jika masyarakat ingin pergi ke pasar yang jaraknya cukup jauh dia harus menggunakan kendaraan pribadi (bagi yang punya) tetapi untuk masyarakat yang tidak memiliki transportasi pribadi terpaksa mereka harus berjalan kaki yang jaraknya cukup jauh dari tempat tinggal mereka.

Sedangkan untuk komunikasi dan informasi masyrakat Kampung Rahong Hilir Desa Tegallega Kecamatan Cigudeg Kabupaten Bogor tidak sama seperti di kota pada umumnya yang mudah mengakses berbagai informasi. Komunikasi di Kampung Rahong Hilir Desa Tegallega Kecamatan Cigudeg Kabupaten Bogor sangatlah terbatas dalam hal untuk mendapatkan sinyal dan juga informasi-informasi yang harusnya mereka dapatkan.

Jika mereka ingin mendapatkan informasi yang lebih luas mereka harus mendatangi tempat-tempat tertentu yang terdapat sinyal seperti di jendela sekolahan, di atas pergi ke desa untuk mendapatkan sinyal tersebut.

\section{Bidang Ekonomi}

Bidang Ekonomi adalah faktor yang sangat mempengaruhi perekonomian serta kesejahteraan masyarakat. Masyarakat Kampung Rahong Hilir Kecamatan Cigudeg Kabupaten Bogor memiliki banyak sektor usaha ekonomi. Adapun perekonomian di Kampung Rahong Hilir Kecamatan Cigudeg Desa Tegallega Kabupaten Bogor cukup stabil, yang banyak memiliki atau didapat dari hasil pertanian dan perkebunan.

Banyak permasalahan di bidang ekonomi di Kampung Rahong Hilir Desa Tegallega Kecamatan Cigudeg Kabupaten Bogor, yaitu :

a. Banyak yang tidak memiliki perkerjaan tetap (penghasilan tidak tentu). Penghasilan petani minim dan hanya setahun sekali masa tanam.

b. Tingginya pengangguran baik terdidik maupun tidak terdidik.

c. Minimnya lowongan pekerjaan.

d. Kurangnya keterampilan (life skill).

e. Sulitnya akses kredit di bank dan praktek bunga bank yang tinggi.

f. Jiwa wirausaha yang kurang.

Dari permasalahan di atas, banyak masalah yang di jumpai yang berkenaan dengan keadaan pemasaran. Pelatihan bukan saja harus dilakukan namun juga 
harus memiliki tindak lanjut serta kesadaran untuk merubah pola kelakuan yang telah dilakukan yang telah dilakukan sebelumnya. Kesadaran untuk berubah juga perlu ditingkatkan agar mendapatkan hasil yang

Tabel 1 Potensi dan masalah di Kampung Rahong Hilir Desa Tegallega

\begin{tabular}{|c|c|c|c|}
\hline No. & Masalah & Penyebab & $\begin{array}{l}\text { Potensi Kampung } \\
\text { Rahong Hilir }\end{array}$ \\
\hline 1. & $\begin{array}{l}\text { Sarana pertanian yang kurang } \\
\text { yaitu saluran irigasi }\end{array}$ & Kurangnya dana & Lahan dan SDM \\
\hline 2. & $\begin{array}{l}\text { Tidak memiliki pekerjaan tetap } \\
\text { (Penghasilan tidak tentu ) }\end{array}$ & $\begin{array}{l}\text { Tidak ada keterampilam } \\
\text { (skill) }\end{array}$ & Lahan dan SDM \\
\hline 3. & $\begin{array}{l}\text { Penghasilan petani minim dan } \\
\text { hanya setahun sekali masa tanam. }\end{array}$ & $\begin{array}{l}\text { Kurangnya keterampilan } \\
\text { dalam pemanfaatan lahan. }\end{array}$ & Lahan dan SDM \\
\hline 4. & $\begin{array}{l}\text { Tingginya pengangguran baik } \\
\text { terdidik maupun yang tidak } \\
\text { terdidik }\end{array}$ & $\begin{array}{l}\text { Tidak ada keterampilan } \\
\text { (skill) }\end{array}$ & Lahan dan SDM \\
\hline
\end{tabular}

Sebagai sebuah potensi lokal yang dimiliki di wilayah Desa Tegallega ini bisa menjadi sebuah alternatif upaya untuk meningkatkan kesejahteraan masyarakat Tegallega sendiri.

Disini kami mencoba untuk memberikan wacana baru kepada masyarakat terkait diversifikasi produk berbahan dasar durian dan gula aren melalui aneka kuliner durian dan gula aren (wajik durian). Harapannya dengan adanya keterampilan-keterampilan tersebut masyarakat dapat termotivasi untuk mengembangkan usaha dengan memanfaatkan potensi-potensi lokal yang ada tanpa mengurangi aspek konservasi yang bertanggung jawab di dalam pemanfaatannya.

Permasalahan yang lain adalah terdapat cukup banyak pohon aren, namun selama ini masih terkendala pada pemanfaatan pohon aren untuk pembuatan gula dan daya jualnya masih belum begitu tinggi, sehingga berdasarkan hal inilah kami ingin memberikan wacana baru kepada masyarakat tentang bagaimana membuat berbagai variasi dalam mengolah pohon aren serta memberikan pengetahuan tentang pentingnya packing dalam meningkatkan nilai jual sebuah produk.

Menginovasi berbagai olahan makanan dimana bahan utama olahan makanan diambil dari potensi alam yang ada di daerah lebih pasti. Potensi dan masalah di Kampung Rahong Hilir Desa Tegallega Kecamatan Cigudeg Kabupaten Bogor dalam bidang ekonomi di gambarkan dalam tabel 1. sekitar dan pelaksanaannya sudah tercapai yaitu pengolahan gadung menjadi keripik gadung dengan berbagai varian rasa ,pengolahan durian menjadi wajik durian dimana cara pengemasan wajik tersebut unik dan pengolahan gula aren menjadi es krim gula aren yang sangat nikmat dan diminati banyak orang.

Banyak permasalahan yang di jumpai yang berkenaan deangan keadaan pemasaran. Pelatihan bukan saja di lakukan namun harus memiliki tindak lanjut serta kesadaran untuk merubah pola kelakuan yang telah lakukan sebelumnya. Kesadaran untuk berubah juga perlu ditingkatkan agar memperoleh hasil yang baik dan pasti.

\section{Bidang Agama}

Dari bidang agama, mengadakan pembelajaran BTAQ (Baca Tulis Alqur an) dan tajwid di mana di dalam pelaksanaan kegiatan ini, warga semangat dan antusias. Dan program ini sudah terlaksana dan tercapai. Sarana prasarana peribadatan yang ada di Desa Tegallega Kecamatan Cigudeg Kabupaten Bogor terdiri dari 5 Masjid besar, dan 10 Mushola yang tersebar di setiap kampung.

Di Kampung Rahong Hilir Desa Tegallega Kecamatan Cigudeg Kabupaten Bogor kami mengadakan pembelajaran BTAQ (Baca 
Tulis Alqur an) dan tajwid untuk anak-anak dan juga lansia. Dimana dalam pelaksanaan kegiatan ini, warga sangat semangat dan antusias. Dan kegiatan ini dapat terlaksana dan tercapai. Dengan diadakannya pembelajaran BTAQ (Baca Tulis Alqur an) dan Tajwid ini diharapkan warga bisa meningkatkan mutu pembacaan, penulisan dan tempat keluarnya huruf (makharijul huruf) dan juga untuk meningkatkan mutu baca tulis Al-Qur'an warga Kampung Rahong Hilir Desa Tegallega Kecamatan Cigudeg Kabupaten Bogor.

\section{Pembahasan}

Berbagai potensi yang dimiliki oleh Desa Tegallega tepatnya di kampung Rahong Hilir masih belum secara optimal dieksplorasi untuk menjadi sumber peningkat kesejahteraan hidup masyarakat.

Salah satu yang menjadi potensi dari wilayah tersebut adalah durian, kweni, petai, jengkol dan pohon aren yang tumbuh disetiap lahan kosong yang ada kampung Rahong Hilir. Sebagai sebuah potensi lokal yang dimiliki di wilayah Desa Tegallega ini bisa menjadi sebuah alternatif upaya peningkatan kesejahtraan masyarakat di Tegallega sendiri.

Kami ingin mencoba untuk memberikan wacana pada masyarakat terkait diversifikasi produk berbahan dasar durian dan gula aren melalui aneka kuliner durian dan gula aren (wajik durian). Diharapkan dengan adanya kegiatan keterampilanketerampilan di masyarakat dapat memberikan motivasi dalam mengembangkan potensi dan usaha tanpa mengurangi aspek konservasi yang bertanggung jawab di dalam pemanfaatannya.

Permasalahan yang lain adalah terdapat cukup banyak pohon aren, namun selama ini masih terkendala pada pemanfaatan pohon aren untuk pembuatan gula dan daya jualnya masih belum begitu tinggi, sehingga berdasarkan hal inilah kami ingin memberikan wacana pada masyarakat tentang bagaimana membuat berbagai variasi dalam mengolah pohon aren serta dapat memberikan pengetahuan dan pengalaman dalam kegiatan menginovasi hasil dari sumber daya alam yang ada di lingkungan sekitar.

Permasalahan dibidang pendidikan yang terjadi di masyarakat adalah kurangnya kesadaran tentang pentingnya pendidikan di dalam kehidupan. Terbukti dengan jumlah sebagian besar penduduk tingkat pendidikannya adalah SD yang mencapai 1.564 orang, penduduk dengan tingkat pendidikan SMP berjumlah 571 orang, SMA 293 orang dan perguruan tinggi 17 orang.

Sebuah hal yang cukup mengagetkan melihat wilayah Desa Tegallega Kampung Rahong Hilir Kecamatan Cigudeg yang masih berada di wilayah Kabupaten Bogor. Selain itu meskipun Desa Tegallega memiliki letak yang masih berada di wilayah Kabupaten Bogor, namun kehidupan pendidikan bagi anak-anak dan juga bagi para pemuda terutama di usia sekolah kurang mendapat respon dan juga perhatian yang lebih agar bisa mencapai kondisi yang optimal.

Mengacu pada tujuan Universitas Djuanda Bogor yang merupakan pencetak-pencetak calon pengajar bangsa, sekaligus pencetak calon konserver-konserver yang peduli akan karakter bangsa, maka kami ingin mengadakan bimbingan belajar bagi anakanak SD yang berada di wilayah tersebut, bagi orang tua terutama di usia lansia kami ingin melaksanakan bimbingan belajar mengenal huruf dengan harapan dapat lebih mengembangkan kualitas SDM bangsa kita.

Belajar Bersama Masyarakat (BBM) adalah sebuah kegiatan kelompok 20 Fakultas Ilmu Keguruan dan Ilmu Pendidikan (FKIP) Universitas Djuanda. Untuk memecahkan masalah-masalah di masyarakat mahasiswa yang tergabung dalam kelompok KKN dapat turut serta membantu memecahkan permasalahan yang dihadapi masyarakat di wilayah pelaksanaan KKN.

Pelaksanaan KKN aktifitas keilmuan dan non keilmuan mahasiswa kepada masyarakat dengan melakukan serangkaian kegiatan yang berkolerasi langsung BBM yang dilakukan di kegiatan ini memiliki 
maksud untuk meningkatan relefansi pendidikan perkembangan dan kebutuhan masyarakat akan ilmu pengetahuan dan teknologi untuk tercapainya pembangunan yang semakin meningkat.

Selain itu (BBM) dilaksanakan untuk pemberdayaan masyarakat. Dengan demikian BBM diharapkan dapat memberikan pengalaman kepada mahasiswa sebagai penerus pembangunan yang lebih menghayati permasalahan yang kompleks dalam masyarakat, sekaligus melakukan kegiatan Belajar Bersama Masyarakat (BBM) untuk menanggulangi berbagai masalah yang ada di dalam masyarakat secara prakmatis dan interdispliner sebagai nilai tambahan mahasiswa itu sendiri tercapainya harapan ini akan dapat membentuk masyarakat yang benar-benar menjadi berdaya untuk mengembangkan daerahnya secara mandiri, sehingga mempercepat tercapainya cita-cita pembangunan Nasional.

Selain itu di Desa Tegallega terdapat 1 PAUD, 1 taman kanak-kanak (TK),dan 4 SD/MI yang terdiri dari 3 SD Negeri yaitu SDN Nunggaherang 1 dan 2, SDN Batu Jajar 04, dan 1 MI yaitu MI Anuriyatul Khoiriyah. Namun Pendidikan Anak Usia Dini (PAUD) yang ada di kelurahan tersebut kurang begitu optimal ditinjau dari segi pelaksanaannya sendiri.

PAUD yang terbentuk dalam kelurahan tersebut terbentuk atas insiatif dari perseorangan. Melihat berbagai fenomena yang terjadi di masyarakat banyak berbagai permasalahan seperti halnya masih kurangnya kesadaran masyarakat akan pentingnya pendidikan yang menunjukan lemahnya karakter dan mentalitas bangsa kita. Sehingga kembali mengacu pada program Universitas Djuanda Bogor terutama dalam konservasi yang di sini juga merujuk pada konservasi karakter bangsa maka, kami berinisiatif untuk melakukan penanaman pembiasaan menyadarkan pentingnya dunia pendidikan.

Kemudian permasalahan di bidang kesehatan yang selama ini terjadi di Desa Tegallega adalah kurangnya kesadaran masyarakat terhadap lingkungan sehingga rentan terkena berbagai macam penyakit. Penyakit yang sering dikeluhkan oleh masyarakat adalah penyakit kulit.

Masyarakat masih kurang peduli tentang bagaimana menjaga lingkungan dan tubuhnya sendiri, kemudian juga bagaimana menjaga kesehatan masyarakat dan berbagai masalah tentang penyakit yang sering menyerang warga desa Tegallega membuat kami berinisiatif bahwa dibutuhkan sosialisasi tentang kesehatan bagi masyarakat.

Selain itu, melihat kurang pedulinya masyarakat terutama terhadap sampah rumah tangga. Banyak sampah tidak berguna hanya di buang sembarangan sekitar terutama di sungai yang pada akhirnya membuat lingkungan menjadi kurang nyaman dan tidak bersih.

Sementara di bidang infrastruktur, melihat kurang tertatanya wilayah Tegallega meskipun sebenarnya wilayahnya cukup subur. Sekaligus sebagai mahasiswa Universitas Djuanda Bogor yang juga berkewajiban untuk menyebarluaskan semangat konservasi, maka kami ingin melakukan pembenahan dengan membenahi sampah yang ada di desa untuk menjadi lingkungan yang sehat dan bersih. Serta tidak lupa pembuatan tempat sampah yang selalu menjadi kegiatan Universitas Djuanda Bogor dalam upaya menyebarkan semangat sehat dan bersih.

\section{KESIMPULAN DAN IMPLIKASI}

\section{Kesimpulan}

Secara umum pelaksanaan Kuliah Kerja Nyata (KKN) Fakultas Keguruan dan Ilmu Pendidikan (FKIP) ini dapat terlaksana dengan baik dan lancar dengan indikator berbagai kegiatan dapat $100 \%$ terlaksana. Adapun kegiatan yang terdiri dari empat bidang pokok adalah sebagai berikut:

Dari bidang pendidikan, mengurangi buta huruf bagi lanjut usia telah berhasil dilaksanakan. Kemudian pelaksanaan 
bimbingan belajar/les, memberikan semangat belajar dan minat dalam mengembangkan ilmu di dalam materi pelajaran lebih meningkat bagi siswa. Permasalahan dibidang pendidikan yang ada di masyarakat adalah kurangnya minat dan kesadaran tentang pendidikan di dalam kehidupan

Dari bidang kesehatan, Desa Tegallega Kecamatan Cigudeg Kabupaten Bogor telah menyiapkan PUSTU (Puskesmas Pembantu) untuk melayani masyarakat dan meningkatkan kesadaran masyarakat dalam hal kesehatan. Masyarakat masih kurang peduli tentang bagaimana menjaga lingkungan dan tubuhnya sendiri, kemudian juga bagaimana menjaga kesehatan masyarakat dan berbagai masalah tentang penyakit yang sering menyerang warga Desa Tegallega Kampung Rahong Hilir membuat kami berinisiatif bahwa dibutuhkan sosialisasi tentang kesehatan bagi masyarakat

Dari bidang lingkungan, mengadakan jumat bersih (jumsih) di lingkungan sekitar yang pelaksanaan program nya telah tercapai untuk meningkatkan kebersihan dan kesehatan di lingkungan sekitar. Pembuatan bak sampah di mana dalam pelaksanaan ini dapat menciptakan kesadaran untuk membuang sampah pada tempatnya.

Dari bidang ekonomi, menginovasi berbagai olahan makanan dimana bahan utama olahan makanan di ambil dari potensi alam yang ada di daerah sekitar dan pelaksanaannya sudah tercapai yaitu pengolahan gadung menjadi keripik gadung dengan berbagai varian rasa, pengolahan durian menjadi wajik durian dimana cara pengemasan wajik tersebut unik dan pengolahan gula aren menjadi es krim gula aren yang sangat nikmat dan di minati banyak orang.

Dari bidang agama, mengadakan pembelajaran BTAQ dan tajwid di mana dalam pelaksanaan program ini, warga sangat antusias dan semangat. Dan program ini telah tercapai dan terlaksana.

\section{Implikasi}

Implikasi Kegiatan KKN ini dapat memberdayakan masyarakat dibidang pendidikan, lingkungan, ekonomi dan agama. Untuk kelancaran kegiatan tersebut perlu adanya sinergitas antara masyarakat dan Dinas terkait dalam melakukan program pemberdayaan masyarakat sehingga pemberdayaan masyarakat tidak berjalan sendiri-sendiri terutama dalam penyediaan modal pemasaran sarana dan prasarana.

Sebagai sebuah potensi lokal yang dimiliki di wilayah Kampung Rahong Hilir Desa Tegallega Kecamatan Cigudeg Kabupaten Bogor ini bisa menjadi sebuah alternatif upaya peningkat kesejahteraan masyarakat Desa Tegallega sendiri. Kami ingin mencoba untuk memberikan wacana baru kepada masyarakat terkait diversifikasi produk berbahan dasar.

Harapannya, dari kegiatan ini masyarakat mampu mengembangkan potensi yang ada di wilayah sekitar tanpa mengurangi aspek konservasi yang bertanggung jawab di dalam pemanfaatannya.

\section{UCAPAN TERIMA KASIH}

Ucapan terima kasih yang sebesar-besarnya kepada Badan Perencanaan Pembangunan Daerah (BAPPEDA) selaku lembaga teknis daerah di bidang penelitian dan perencanaan pembangunan daerah serta Kepala Desa Tegallega Bapak H.Samsu beserta jajaran dan kepala Yayasan Insan madani Bapak $\mathrm{H}$. Muhdi Nurdiansyah, M.M.

\section{DAFTAR PUSTAKA}

Perangkat Desa, 2017, Monografi Desa Tegallega. Kabupaten Bogor.

Profil Desa Tegallega

BP-LPKM UNIDA. 2017. Kuliah Kerja Nyata PM. Universitas Djuanda Bogor. Jawa Barat. 